\title{
Record of predation by two amphibians Rhinella major and Ctenophryne geayi by Erythrolamprus dorsocorallinus (Esqueda, Natera, La Marca \& Ilija-Fistar, 2005) (Serpentes: Dipsadidae) in northwestern Brazil
}

\author{
J. S. Araújo ${ }^{a *}$, F. Corrêa ${ }^{b}$, L. J. Soares ${ }^{b}$ and M. B. Souza ${ }^{a}$ \\ ${ }^{a}$ Laboratório de Herpetologia, Universidade Federal do Acre - UFAC, Campus Universitário Áulio Gélio Alves de Souza, \\ BR 364, Km 04, Distrito Industrial, CEP 69915-900, Rio Branco, AC, Brasil \\ ${ }^{\text {b} L a b o r a t o ́ r i o ~ d e ~ I c t i o l o g i a, ~ U n i v e r s i d a d e ~ F e d e r a l ~ d o ~ A c r e ~-~ U F A C, ~ C a m p u s ~ U n i v e r s i t a ́ r i o ~ A ́ u l i o ~ G e ́ l i o ~ A l v e s ~ d e ~ S o u z a, ~ B R ~}$ \\ 364, Km 04, Distrito Industrial, CEP 69915-900, Rio Branco, AC, Brasil \\ *email: jaillini@gmail.com
}

Received: July 22, 2016 - Accepted: May 17, 2017 - Distributed: November 30, 2018

(With 1 figure)

Snakes have a major importance in the food chain, acting in the connection and transfer of energy between different trophic levels (Bernarde and Machado, 2002; Hartmann et al., 2003). The neotropical genus Erythrolamprus Boie, 1826 include 50 species of snakes with wide distribution in South and Central America (Curcio et al., 2009; Vidal et al., 2010; Grazziotin et al., 2012). Erythrolamprus dorsocorallinus features an exuberant color pattern but little is known about its distribution and ecology. The species is originally described from Venezuela (Esqueda et al., 2007), and recently recorded was recorded in the westernmost part of the Brazilan Amazonia (Bernarde et al., 2011; Pantoja and Fraga, 2012; Araújo et al., 2012; Miranda et al., 2014; Eversole et al., 2016). Data on natural history of this taxon is virtually inexistent, and the species does not have any kind of information available about its trophic ecology, reproduction or function in community, with highlighted only for one study in the Venezuela (e.g. Mumaw et al., 2015). To help filling this gap, this paper records the predation of amphibians by two individuals of E. dorsocorallinus, in a forest fragment in the state of Acre, Brazil. One specimen (collection number UFAC 396) was collected in pitfall traps, in February 2012 in the Zoobotanical Park of the Federal University of Acre (9'57'05.35'S, 67'52'26.23”W). The second specimen (UFAC 503) was captured manually in January 2013, on the main campus of the Federal University of Acre, in Rio Branco (9'57'26”S, 6752'25'W), both in the state of Acre, northwestern Brazil. Specimens were collected under a permit from the Brazilian Environmental Ministry (SISBIO \#37974-1). The two areas feature vegetation consisting of mature riparian forest and predominantly secondary formations at different stages of ecological succession. Specimens were identified following diagnostic characters and description in Esqueda et al. (2007), fixed in $10 \%$ formalin, preserved in alcohol $70 \%$, and deposited in the herpetological collection of the Federal University of Acre. For each specimen, we measured snout-vent length (SVL) from tip of snout to tip of tail. We recorded prey items in the digestive tract of snakes. For all vertebrate prey items, we recorded their snout-vent length (SVL) and weight (W) with a digital scale.

The two specimens of $E$. dorsocorallinus were females, SVL $515 \mathrm{~mm}$ and $490 \mathrm{~mm}$ (Figure 1a). From each individual, one species of amphibians were recorded in their stomach contents, Rhinella major (71 mm SVL) and Ctenophryne geayi (79 mm SVL) (Figure 1b).

Rhinella major is a species of Bufonidae with average length of $53 \mathrm{~mm}$ in adult males and $54 \mathrm{~mm}$ in adult females. This species is distributed in different countries in the Neotropical region, common in secondary forest and open areas (Narvaes and Rodrigues, 2009). Ctenophryne geayi is a Microhylidae with range length $32-43 \mathrm{~mm}$ in males and $42-55 \mathrm{~mm}$ in females (La Marca et al., 2010). This is a fossorial species which is mostly found in primary forests and is wide distributed in northern South America (Zweifel and Myers, 1989; La Marca et al., 2010).

The composition of food items can be influenced by the availability of prey in the area, that is, when they are found in abundance they are, consequently, more consumed (Macedo et al., 2008). Information on the types of prey consumed by each species of snake are necessary to describe for example, the diet and establishment of trophic guilds (Vitt and Vangilder, 1983) as well as information on the substrate used for foraging (Martins et al., 2002; França et al., 2008). Indeed, the studies that report first records of predation generate important information for future studies on trophic ecology, as well management of species conservation. This paper is the first report of the ingestion of Rhinella major and Ctenophryne geayi by E. dorsocorallinus and is crucial to a better knowledge of trophic ecology of the snakes of this important region of the Amazon. 
A)
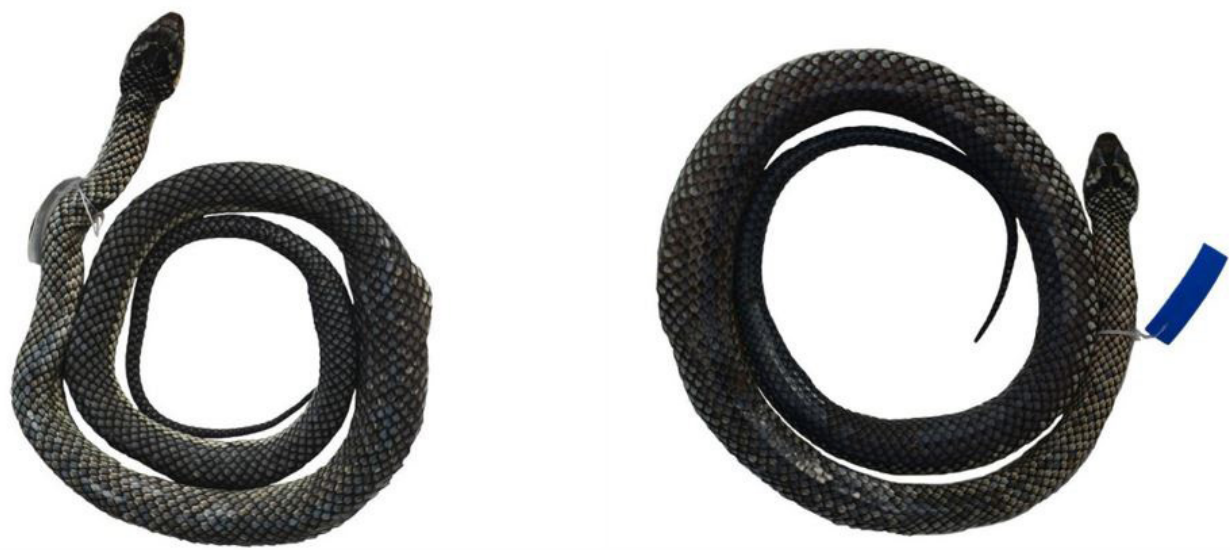

B)

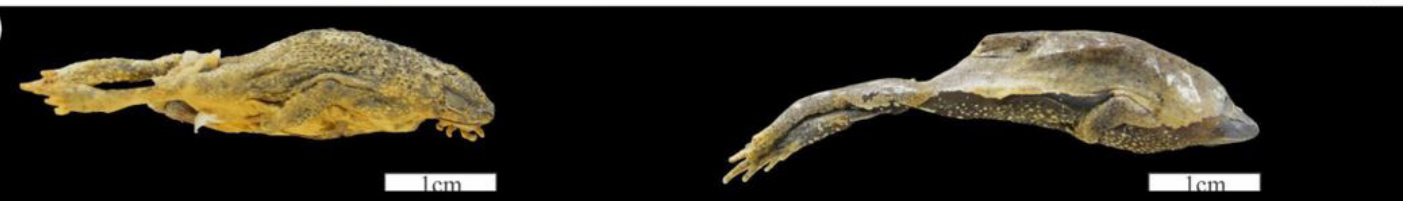

Figure 1. Specimens of E. dorsocorallinus above (A) and prey below (B): Rhinella major (left) and Ctenophryne geayi (right) (Picture by Fabiano Corrêa).

\section{Acknowledgements}

We thank the anonymous reviewers for their suggestions and Dr. Pedro Peloso for review of the manuscript.

\section{References}

ARAÚJO, J.S., SOUZA, M.B., FARIAS, T.A., SILVA, D.P., VENÂNCIO, N.M., MACIEL, J.M.L. and MELO-SAMPAIO, P.R., 2012. Liophis dorsocorallinus Esqueda, Natera, La Marca and Ilija Fistar, 2007 (Squamata: Dipsadidae): Distribution extension in southwestern Amazonia, state of Acre, Brazil. Check List, vol. 8, no. 3, pp. 518-519. http://dx.doi.org/10.15560/8.3.518.

BERNARDE, P.S. and MACHADO, R.A., 2002. Fauna reptiliana da Bacia do rio Tibagi. In: M.E. MEDRI, E. BIANCHINI, O.A. SHIBATTA and J.A. PIMENTA, eds. A Bacia do rio Tibagi. Londrina: Edição dos Autores, pp. 291-296.

BERNARDE, P.S., MACHADO, R.A. and TURCI, L.C.B., 2011. Herpetofauna da área do Igarapé Esperança na Reserva Extrativista Riozinho da Liberdade, Acre-Brasil. Biota Neotropica, vol. 11 , no. 3, pp. 117-144. http://dx.doi.org/10.1590/S167606032011000300010

CURCIO, F.F., PIACENTINI, V. and FERNANDES, D.S., 2009. On the status of the snake genera Erythrolamprus Boie, Liophis Wagler and Lygophis Fitzinger (Serpentes, Xenodontinae). Zootaxa, vol. 2173, pp. 66-68.

ESQUEDA, L.F., NATERA, M., LA MARCA, E. and ILIJAFISTAR, M., 2007. Nueva especie de serpiente (Reptilia: Colubridae: Liophis) de un bosque tropical relictual en el estado Barinas, Venezuela. Herpetotropicos, vol. 2, no. 2, pp. 95-103.

EVERSOLE, C.B., POWELL, R.L., LIZARRO, D. and CHOLIMA, B.R., 2016. Erythrolamprus (Liophis) dorsocorallinus, Esqueda, Natera, La Marca and Ilija-Fistar, 2007 (Squamata:Dipsadidae): range extension, new country record, and comments on color pattern. Biotaxa, vol. 12, no. 6, pp. 1-4.

FRANÇA, F.G.R., MESQUITA, D.O., NOGUEIRA, C.C. and ARAÚJO, A.F.B., 2008. Phylogeny and ecology determine morphological structure in a snake assemblage in the Central brazilian Cerrado. Copeia, vol. 1, no. 1, pp. 23-38. http://dx.doi. org/10.1643/CH-05-034.

GRAZZIOTIN, F.G., ZAHER, H., ROBERT, W.M., SCROCCHI, G., BENAVIDES, M.A., ZHANG, Y.-P. and BONATTO, S.L., 2012. Molecular phylogeny of the New World Dipsadidae (Serpentes: Colubroidea): a reappraisal. Cladistics, vol. 28, no. 1, pp. 1-23.

HARTMANN, P.A., HARTMANN, M.T. and GIASSON, L.O.M., 2003. Uso do hábitat e alimentação em juvenis de Bothrops jararaca (Serpentes, Viperidae) na Mata Atlântica do sudeste do Brasil. Phyllomedusa, vol. 235, no. 2, pp. 35-41. http://dx.doi. org/10.11606/issn.2316-9079.v2i1p35-41.

LA MARCA, H., COLOMA, L.A., RON, S. and AMORÓS, C.L.B., 2010 [viewed 7 July 2016]. Ctenophryne geayi. Version 2013.2. IUCN Red List of Threatened Species. Available from: http://www.iucnredlist.org/.

MACEDO, L.C., BERNARDE, P.S. and ABE, A.S., 2008. Lagartos (Squamata: Lacertilia) em áreas de floresta e de pastagem em Espigão do Oeste, Rondônia, sudoeste da Amazônia. Biota Neotropica, vol. 8, no. 1, pp. 133-139.

MARTINS, M., MARQUES, O.A.V. and SAZIMA, I., 2002. Ecological and phylogenetic correlates of feeding habits in Neotropical pitvipers (Genus Bothrops). In: G.W. SCHUETT, M. HÖGGREN, M.E. DOUGLAS and H.W. GREENE, eds. Biology of the vipers. Eagle Mountain: Eagle Mountain Publishing. pp. 307-328.

MIRANDA, D.B., VENÂNCIO, N.M. and ALBUQUERQUE, S., 2014. Rapid survey of the herpetofauna in an area of forest management in eastern Acre, Brazil. Check List, vol. 10, no. 4, pp. 893-899. 
MUMAW, M.N., GONZÁLEZ, L.F.E. and FERNÁNDEZ, M.C., 2015. Atlas serpientes de Venezuela: una visión actual de su diversidade. $440 \mathrm{p}$.

NARVAES, P. and RODRIGUES, M.T., 2009. Taxonomic revision of Rhinella granulosa species group (Amphibia, Anura, Bufonidae), with a description of a new species. Arquivos de Zoologia, vol. 40, no. 1, pp. 1-73. http://dx.doi.org/10.11606/ issn.2176-7793.v40i1p1-73.

PANTOJA, D.L. and FRAGA, R., 2012. Herpetofauna of the Reserva Extrativista do Rio Gregório, Juruá Basin, southwest Amazonia, Brazil. Check List, vol. 8, no. 3, pp. 360-364.
VIDAL, N., DEWYNTER, M. and GOWER, D.J., 2010. Dissecting the major American snake radiation: a molecular phylogeny of the Dipsadidae Bonaparte (Squamata, Caenophidia). Comptes Rendus Biologies, vol. 333, no. 1, pp. 48-55. PMid:20176336. http://dx.doi.org/10.1016/j.crvi.2009.11.003.

VITT, L.J. and VANGILDER, L.D., 1983. Ecology of a snake community in Northeastern Brazil. Amphibia-Reptilia, vol. 4, no. 2, pp. 273-296. http://dx.doi.org/10.1163/156853883X00148.

ZWEIFEL, R.G. and MYERS, C.W., 1989. A new frog of the genus Ctenophryne (Microhylidae) from the Pacific lowlands of northwestern South America. American Museum Novitates, vol. 2947, pp. 1-16. 